\title{
The expectations theory and the founding of the fed: another look at the evidence
}

Citation for published version (APA):

Kool, C. J. M., \& Thornton, D. (2000). The expectations theory and the founding of the fed: another look at the evidence. METEOR, Maastricht University School of Business and Economics. METEOR Research Memorandum No. 009 https://doi.org/10.26481/umamet.2000009

Document status and date:

Published: 01/01/2000

DOI:

10.26481/umamet.2000009

Document Version:

Publisher's PDF, also known as Version of record

\section{Please check the document version of this publication:}

- A submitted manuscript is the version of the article upon submission and before peer-review. There can be important differences between the submitted version and the official published version of record.

People interested in the research are advised to contact the author for the final version of the publication, or visit the DOI to the publisher's website.

- The final author version and the galley proof are versions of the publication after peer review.

- The final published version features the final layout of the paper including the volume, issue and page numbers.

Link to publication

\footnotetext{
General rights rights.

- You may freely distribute the URL identifying the publication in the public portal. please follow below link for the End User Agreement:

www.umlib.nl/taverne-license

Take down policy

If you believe that this document breaches copyright please contact us at:

repository@maastrichtuniversity.nl

providing details and we will investigate your claim.
}

Copyright and moral rights for the publications made accessible in the public portal are retained by the authors and/or other copyright owners and it is a condition of accessing publications that users recognise and abide by the legal requirements associated with these

- Users may download and print one copy of any publication from the public portal for the purpose of private study or research.

- You may not further distribute the material or use it for any profit-making activity or commercial gain

If the publication is distributed under the terms of Article $25 \mathrm{fa}$ of the Dutch Copyright Act, indicated by the "Taverne" license above, 


\title{
THE EXPECTATIONS THEORY AND THE FOUNDING OF THE FED: ANOTHER LOOK AT THE EVIDENCE
}

\author{
Clemens J.M. Kool and Daniel L. Thornton
}

November 2000

\begin{abstract}
One of the most influential contributions to the literature on the expectations theory of the term structure of interest rates is Mankiw and Miron (1986), who found support for the expectations theory prior to the founding of the Fed but not after. Mankiw and Miron suggested that the failure of the expectations theory after the Fed's founding was due to the Fed's practice of smoothing short-term interest rates. In this paper we show that Mankiw and Miron's findings are the result of a bias in the test that they employ. This bias arises when the short-term rate is excessively volatile, as it was during the financial panic of 1907 . We argue that our finding that there was no more evidence supporting the expectations theory before the Fed's founding than after is consistent with the Fed's limited activity during its formative years. We argue that it is unlikely that the Fed actually pursued a policy of smoothing interest rates during the early years of its existence. But, even if it had, we argue that it is unlikely that such a policy accounts for the marked change in the behavior of interest rates.
\end{abstract}

\section{JEL Classification: E40, E52}

Key Words: expectations theory; bias; Fed's founding; measurement error.

Clemens J. M. Kool [c.kool@algec.unimaas.nl] is Professor of Money and Banking at the University of Maastricht and Daniel L. Thornton [thornton@stls.frb.org] is Vice President and Economic Advisor, at the Federal Reserve Bank of St. Louis. The views expressed here are the authors' and do not necessarily reflect the views of the Board of Governors of the Federal Reserve System or the Federal Reserve Bank of St. Louis. We would like to thank Robert Rasche for helpful comments and Stephen Majesky and Tom Pollmann for valuable research assistance. 


\section{Introduction}

The expectations theory of the term structure of interest rates plays an important role in economics and finance, so it is not surprising that the relationship between shortterm and long-term interest rates has been investigated thoroughly. In nearly every case, the expectations theory is rejected [e.g., Campbell and Shiller (1991), Froot (1989), and Rudebusch (1995)]. Nevertheless, the hypothesis that the long-term rate is equal to the average of the market's expectation for the short-term rate is commonly used in theoretical analyses of monetary policy [e.g., Rudebusch (1995) and Clarida, Gali and Gertler (1999)].

One reason for the expectations theory's acceptance is that one of the most frequently used tests of it, which we call the conventional test, tends to yield results that are generally supportive of it. Specifically, the spread between the long-term rate and the short-term rate appears to explain a significant portion of the long-term change in the short-term rate. One of the most influential applications of the conventional test is Mankiw and Miron (1986), henceforth MM, who "confirm the failure of the expectations theory using recent data", but "find that the expectations theory works much better during some previous monetary regimes, in particular for data prior to the founding of the Fed."

Although the expectations theory is rejected before and after the Fed's founding, MM find that it is strongly rejected after 1914 but only marginally rejected before. They also find that changes in interest rates were predictable before 1914 but not after. They attribute the failure of the expectations theory to the lack of predictability of changes in interest rate after 1914, noting that "the relative success of the theory with data from before the founding of the Fed is attributable to the greater predictability of changes in 
the short rate." 2 They then "speculate that the failure of the expectations theory using post-Fed data may be due to the Federal Reserve's commitment to stabilizing interest rates.",3

We show that MM's finding that the expectations theory fairs better prior to the Fed's founding is due to the fact that the conventional test is biased in favor of the expectations theory during periods when the variances of the short-term rate is high relative to the long-term rate [Thornton's (2000)]. Specifically, we show that MM's conclusion "for data prior to the founding of the Federal Reserve, the slope of the yield curve has substantial predictive power for the path of the short rate," is due to relatively few observations when the short-term rate was unusually variable. ${ }^{4}$ Indeed, three of these observations are shown to have a significant affect on MM's conclusion that the expectations theory fares better prior to the founding of the Fed. Moreover, these observations are associated with the financial panic of 1907 and are subject to measurement error [Fishe and Wohar (1990), Mankiw, Miron and Weil (1987), hereafter MMW, and Mankiw, Miron and Weil (1990)]. Once the bias of the conventional test is accounted for, the expectations theory is shown to fare no better before the founding of the Fed than after.

Having shown that the expectations theory performs no better before the Fed's founding than after, we reconsider MM's explanation for the failure of the expectations theory after the Fed's founding. We argue it is unlikely that the Fed pursued a policy of

\footnotetext{
${ }^{1} \mathrm{MM}$ (1986), p. 213.

${ }^{2}$ Mankiw and Miron (1986), p. 213.

${ }^{3}$ Mankiw and Miron (1986), p. 213.

${ }^{4}$ Mankiw and Miron (1986), p. 213.
} 
interest rate smoothing. Even if it had, we show that it is unlikely that such a policy could account for the unpredictability of interest rates changes after 1914.

The outline of the paper is as follows. In Section 2 we summarize MM's test procedure. Section 3 briefly summarizes Thornton's (2000) analysis of the bias of the conventional test of the expectations theory. A detailed reevaluation of MM's 1890-1914 result is undertaken in Section 4. In Section 5, we show why it is unlikely that a policy of interest rate smoothing accounts for the unpredictability of changes in interest rates after 1914. The conclusions are presented in Section 6.

\section{The Conventional Test of the Expectations Theory}

The expectations theory can be thought of as an arbitrage condition that binds a long-term, $n$-period interest rate, $r_{t}^{n}$, and a sequence of expected future levels of a shortterm, $m$-period rate up till $n-m=(k-1) m$ periods in the future, where $k=n / m$ is an integer. That is,

$$
r_{t}^{n} \boldsymbol{\nabla}(1 / k) \boldsymbol{K}_{i \mathbf{i})}^{k \boxminus n} E_{t} r_{t \mapsto i n i}^{m}=\theta \text {. }
$$

Equation 1 states that the $n$-period rate is equal to the average of the market's expectation at the beginning of period $t, \mathrm{E}_{\mathrm{t}}$, of the series of $m$-period rates over the term of the $n$-period rate plus a constant risk premium, $\theta .^{5}$

A number of tests of the expectations theory have been proposed, but the one that MM employ is the most often used. The conventional test of the expectations theory is derived by assuming that expectations are rational, i.e.,

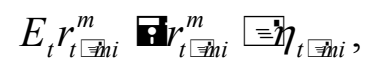

\footnotetext{
${ }^{5}$ Shiller, Campbell and Schoenholtz (1983) argue that Equation 1 is exact in some special cases and that it can be derived as a linear approximation to a number of nonlinear expectations theories of the term structure.
} 
where $\eta_{t \boxminus \nexists n i} \sim \operatorname{iid}\left(0, \sigma_{\eta}^{2}\right)$. Equation 2 is then substituted into Equation 1, to yield,

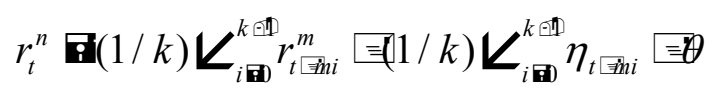

For reasons that will become clear later, the next step in the derivation of the conventional test is crucial. Specifically, the current $m$-period rate is subtracted from both sides of Equation 3 and the equation is rewritten to express Equation 3 in terms of the rate spread, i.e.,

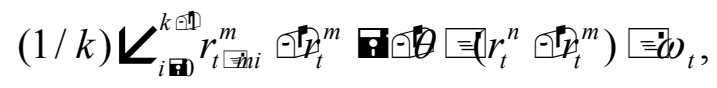

where $\omega_{t}$ follows an $\mathrm{MA}(\mathrm{k})$ process and is orthogonal to all information known at the beginning of the period. The conventional test of the expectations theory is obtained by parameterizing Equation 4, which yields,

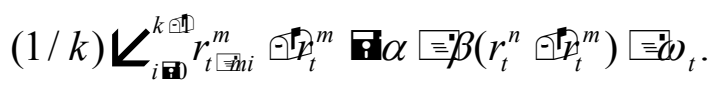

If the expectations theory holds, the null hypothesis that $\beta=1$ should not be rejected.

The conventional test nearly always rejects the expectations theory per se. However, unlike other tests, it usually provides some support for it. Specifically, estimates of $\beta$ are almost always positive and significantly different from zero and the slope of the yield curve often provides predictive power for the path of the short-term rate, as measured by $\bar{R}^{2}$.

\section{The Bias of the Conventional Test}

The conventional test that MM employ nearly always rejects the expectations theory. Some have argued that this is because of the joint hypothesis of rational 
expectations. $^{6}$ Others [e.g., Mankiw (1986), MM, Hardouvelis (1988) and Tzavalis and Wickens (1997)] have attributed this result to a time-varying risk premium that is correlated with the rate spread. ${ }^{7}$ The popularity of the latter explanation has been enhanced by MM's intuitively appealing explanation for the "success" of the expectations theory before the founding of the Fed and for its subsequent failure. Hardouvelis (1994) notes that time-varying risk premium explanation requires a highly volatile term premium and Bekaert and Hodrick (2000, p. 3) note that "the literature has had surprisingly little success generating risk premiums that explain the empirical evidence." 8

Recently, Thornton (2000) has shown that the conventional test is biased in favor of accepting the expectations theory when the expectations theory is false. To see why, note that if Equation 3 is parameterized before the short rate is subtracted, the resulting equation is,

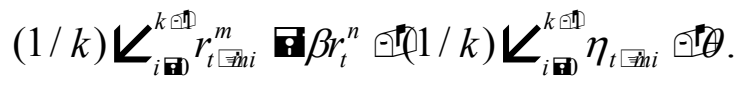

Subtracting $r_{t}^{m}$ from both sides of Equation 6, yields,

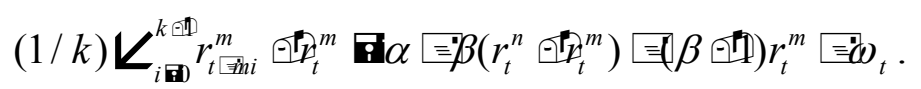

\footnotetext{
${ }^{6}$ Bekaert, Hodrick and Marshall (1997) show that the estimate of $\beta$ is biased upward in small samples when there is extreme persistence of short-term interest rates. Schotman (1997) notes, however, that the bias can be positive or negative depending on the form of the persistence. In any event, this explanation cannot account for the failure of the expectations hypothesis prior to 1914 because interest rates during this period were definitely mean reverting.

${ }^{7}$ While either of these possibilities could account for the failure of the conventional test to accept the expectations theory, neither has received much empirical support. Froot (1989) tested the expectations theory using survey data and rejected it for short-term rates but not for long-term rates. Furthermore, he found that the market's forecasts of future short-term rates are rational.

${ }^{8}$ Tzavalis and Wickens (1997) claim to have found a highly autoregressive term premium that they argue accounts for nearly all of the bias. However, it should be noted that if one accounted for all of the variation in the rate spread with a time-varying risk premium, the test would surely accept the expectations theory because effectively it would be a tautology. This is evident in Tzavalis and Wickens' results in that the Adj. $R^{2}$ is close to 1 in all of the equations where they fail to reject the expectations theory with their proxy for the time varying risk premium.
} 
Note that Equation 7 reduces to Equation 5 if and only if $\beta=1$, i.e., only if the expectations theory is true. Hence, if Equation 5 is estimated but the expectations theory is not true, the least-squares estimator, $\hat{\beta}$, is equal to,

$$
E \hat{\beta} \mathbf{\mathbf { q }} \beta \boxminus(\beta) E \frac{\boldsymbol{K}\left(\bar{r}_{t}^{n}-\bar{r}_{t}^{m}\right) \bar{r}_{t}^{m}}{\boldsymbol{K}\left(\bar{r}_{t}^{n}-\bar{r}_{t}^{m}\right)^{2}},
$$

where the bar denotes that the variable has been adjusted for the mean. The second term on the right hand side of Equation 8 is zero only when $\beta=1$. When $\beta \neq 1$, however, $\hat{\beta}$ will be biased. Moreover, the bias does not disappear in large samples, i.e.:

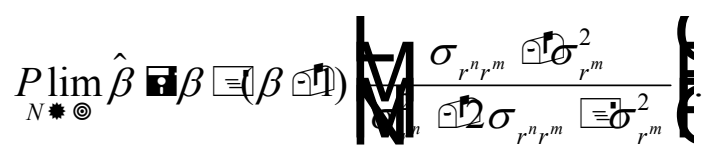

Noting that $\sigma_{r^{n} r^{m}} / \sigma_{r^{n}}^{2} \mathbf{\mathbf { q }} \rho \delta$, where $\rho$ is the coefficient of correlation between $r_{t}^{n}$ and $r_{t}^{m}$ and $\delta \mathbf{\mathbf { q }} \sigma_{r^{m}}^{2} / \sigma_{r^{n}}^{2}$, this expression can be rewritten as,

$$
P_{N \rightarrow \infty} \hat{\beta}=\beta+\left.(\beta-1)\right|_{2 \rho \delta^{1 / 2}+\delta} ^{\delta^{1 / 2}-\delta}
$$

The bias depends on the extent to which $\beta$ differs from 1 and on the bracketed term in Equation 10, called the bias factor, $b f$. In general, $b f$ can either be positive or negative; however, it is strictly negative when the short-term rate is more variable than the long-term rate, i.e., $\delta>1-$ a fundamental prediction of the expectations theory.

Figure 1 shows the bias factor for values of $\rho$ in the interval $[0.01,0.99]$ and values of $\delta$ in the interval $[0.01,10]$. The ridge of points where $b f=-1$ (i.e., where $\delta=\rho^{-2}$ ) is clearly visible. Figure 1 shows how the estimate of $\beta$ can be affected by a few extreme observations of the short-term rate. Not only do such observations tend to raise the variance of the short-term rate relative to the long-term rate, but they also tend 
to simultaneously reduce $\rho$. The combination of a larger $\delta$ and smaller $\rho$ can cause $b f$ to be much closer to -1 .

\section{Another Look at MM's 1890-1914 Results}

\subsection{MM's Evidence}

MM estimate Equation 5 using both monthly and quarterly data, but only present results for the quarterly data. In MM's application $r^{m}$ is the rate on 3-month time loans, $r_{t}^{3}$ and $r^{n}$ is the rate on 6-month time loans, $r_{t}^{6}$, both at New York banks. These rates are presented in Figure 2 for the period 1890-1958. Estimates of Equation 5 using monthly and quarterly data are presented in Panels A and B, respectively, of Table 1 for MM's sub periods. The results using monthly data are very similar to the quarterly results-which are identical to MM's. For the remainder of the paper, only results using monthly data are presented. Based on their results, MM argue that the expectations theory performs well during the 1890-1914 period and conclude [MM, p. 217]:

“...although data from this period do not fully confirm the expectations theory, the slope of the yield curve does contain substantial information on the path of the short rate".

Support for the expectations theory is considerably weaker after 1914, particularly after 1933. Not only are the estimates of $\beta$ much smaller (indeed, negative after 1933), but the estimates of $\bar{R}^{2}$ suggest that the rate spread explains none of the long-term change in the short-term rate.

\subsection{The Behavior of the 3-month Rate}

The behavior of the 3-month and 6-month time loan rates for the period 1890.011914.12 is broadly consistent with the predictions of the expectations theory. For example, during 202 of the 300 months the 6 -month rate was above the 3 -month rate. On 
these occasions, the 3 -month interest rate rose an average of 26 basis points the next month. During the 66 months when the two rates were equal, the 3-month rate rose an average of 43 basis points the next month. Finally, during the 32 months when the yield curve was inverted, the 3-month rate declined an average of 84 basis points the next month.

The problem that these data pose for the expectations theory is that, most often, changes in the slope of the yield curve are the result of the short-term rate changing relative to the long-term rate and not the other way around, as the expectations theory requires. This is particularly true when the yield curve is inverted. When the yield curve inverts, it is not because the 6-month rate fell (portending a decline in the 3-month rate), but because the 3-month rate rose relative to the unchanged or little changed 6-month rate.

The variance of the 3-month rate tends to be high during periods when the yield curve is inverted. When the 32 observations when the yield curve is inverted are deleted, the variance of the 3 -month rate declines by nearly 40 percent, from 2.23 percent to 1.42 percent. In contrast, the variance of the 6-month rate is essentially unchanged, declining from 1.08 percent to 1.04 percent. These observations also have a relatively large affect on $\rho$. The estimate of $\rho$ is 0.94 when these observations are deleted and 0.87 when they are not. Because these observations increase $\delta$ and reduce $\rho$, it is possible that they account for the more favorable results prior to the Fed's founding.

\subsection{The Financial Panic of 1907}

There are three instances when the yield curve was inverted that are particularly important for MM's results. These occurred during the financial panic of 1907. The 
dates are 1907.11, 1907.12 and 1908.01. The spread between the 6-month and 3-month rates for these months was $-800,-300$ and -400 basis points, respectively. These observations are extreme. Indeed, there is only one other month, August 1914, when the absolute value of the rate spread is even 200 basis points. These observations contribute significantly to the variance of the 3-month rate over the 1890-1914 sample period.

\subsubsection{Measurement Problems}

Not only are these three observations extreme, but they are subject to measurement error. The existence of measurement problems in MM's data is well documented [James (1978), Fishe and Wohar (1990) and Mankiw, Miron and Weil (1990)]. For one thing, from 1890 to 1933, a usury provision in the National Banking Act prohibited national banks from charging a higher rate than that fixed by state law or 7 percent if no state law existed [James (1978, pp. 79-88)]. The State of New York had a usury law that set the ceiling on various interest rates, including those on time loans, at 6 percent. Consequently, the 3- and 6-month rates did not exceed 6 percent before 1903 and the 6-month rate was frequently at the 6 percent level for months at a time.

James notes that usury laws were generally ineffective because banks would charge interest in advance, require a commission be paid or require borrowers to maintain a "compensating balance" with the bank. As a result, while there were only a few open violations of the usury law, reported rates of 6 percent or more are unlikely to reflect the effective rates.

In addition, Fishe and Wohar (1990) have identified other specific measurement problems with MM's interest rates. Specifically, they [Fishe and Wohar (1990, p. 968)] note that these rates: 
“...do not always represent market transactions. There were many months in which no business was conducted in the loan market, primarily because of financial panic or distress, and in these months only a "nominal" loan rate was reported. The nominal rate was arbitrarily set at the usury ceiling in New York, which was 6 percent over this period."

Fishe and Wohar conduct an independent investigation of a major data source, the Commercial and Financial Chronicle $(C \& F C)$ - a popular business magazine of the time. They use Andrew (1910) as their source up to 1908 and the $C \& F C$ for the period thereafter. Andrew's convention was to report the average weekly rate on time loans of different maturities from $C \& F C$ for weeks ending on Friday. Andrew also indicates dates on which (1) no transaction occurred at quoted rate, (2) an unknown commission was paid in addition to the legal rate of 6 percent when the ceiling rate was reported, or (3) one of the two rates was not reported. ${ }^{9}$ When one or more of these circumstances arise, Fishe and Wohar identify the observation as being subject to measurement error. Using this criterion, Fishe and Wohar identify the observations on 1907.11 and 1907.12 as being subject to measurement error.

There is a measurement problem with January 1908 that has been overlooked, however. Andrew's weekly data are averages of daily data for weeks ending Friday. Andrew's usual practice is to report the weekly average for the week ending Friday each January. For some unknown reason, Andrew deviated from this practice in 1908. In January 1908, Andrew's observation for the week ending January 3, 1908 is the daily

\footnotetext{
${ }^{9}$ It seems unlikely that Fishe and Wohar have identified all observations that are subject to measurement error. It also seems unlikely that the $C \& F C$ reported all cases where no business was conducted or where a commission was paid. Moreover, James (1978) indicated that banks frequently required borrowers to maintain a compensating balance to raise the effective rate, but the $C \& F C$ did not report instances of banks requiring compensating balances. Finally, Andrew (1910) frequently presents rate ranges rather than a specific rate. When this occurred, MM and MMW used the mid-point of the quoted range. The ranges tend to be much wider [in some cases 400 basis points] when interest rates are at or above the usury limit. Consequently, observations when the rates are at or above 6 percent tend to be less precise than when rates
} 
average for only January 2 and $3 .{ }^{10}$ This is the only instance where Andrew split the reporting week in this fashion. On both of these days the 3-month rate was reported at 10 percent and the 6-month rate was at the usury limit of 6 percent. ${ }^{11}$

\subsubsection{The Effect of These Extreme Observations on MM's Results}

While all of the observations when the variance of the 3-month rate is high have a significant affect on MM's results, it is instructive to focus first on these three very extreme observations. Estimating Equation 5 for the period 1890.01-1914.12 excluding these observations reveals the importance of these three observations to MM's results. The results, reported in Table 2, show that while deleting these three observations has relatively small affect on the estimate of $\beta, \bar{R}^{2}$ drops dramatically—by nearly half. The effect of these observations on the $\bar{R}^{2}$ occurs because these observations have a very large effect on the total sum of squares, TSS, but very little effect on the residual sum of squares, RSS. The latter is evident from Figure 3, which shows a scatter plot of the independent variable and dependent variable, along with the estimated regressions with and without these three observations. The regression line excluding these observations nearly falls on the line with these observations. Consequently, the RSS is nearly the same whether these observations are included or excluded. The TSS is considerably larger when these observations are included, however. As a result, including these observations gives the impression that the rate spread explains a relatively large proportion of the variation in the long-term change in the short-term rate.

\subsection{The Effect of the High Variance Observations on MM's Results}

are below 6 percent. For all of these reasons, potential for measurement problems exist whenever one or the other of the rates is at or above the usury limit.

${ }^{10}$ Likewise, the rate reported for the last week of 1907 is based on the average for the last two days of 1907. 
Even the estimate of $\bar{R}^{2}$ of 20 percent exaggerates the predictive power of the rate spread. The reason is that observations when the variance of the 3 -month rate is high cause a shift in the mean level of the dependent variable, which gives the impression that the slope of the yield curve explains a significant portion of the long-term changes in the short-term rate. To make this point clear Table 3 reports estimates of Equation 5 over various partitions of the data. The first column of Table 3 shows the estimates when the 66 months when the 3-month and 6-month rates were equal are deleted. As one would expect, the estimates of $\beta$ and $\bar{R}^{2}$ are not affected by deleting the observations when the rate spread was zero. The estimates are very sensitive to whether the yield curve is positively sloped or inverted, however. When the yield curve is positively sloped (202 observations) the results are nearly identical to those for the period 1915.01-1933.12. The estimate of $\beta$ drops to 0.42 , and the spread accounts for only 4 percent of the variation in the long-term change in the short-term rate. Hence, there is no support for the expectations theory for two thirds of the sample when the yield curve was positively sloped.

When the yield curve is inverted ( 32 observations), however, the conventional test appears to provide strong support for the expectations theory. The estimate of $\beta$ is 0.66 and the rate spread "explains" about 78 percent of long-term changes in the short-term rate. In this case, however, the apparent support for the expectations theory is due solely to the three months during the financial panic of 1907 . When these observations are deleted, the evidence supporting the expectations theory vanishes. The estimate of $\beta$

\footnotetext{
${ }^{11}$ The following week both rates are reported at the usury limit of 6 percent.
} 
drops by two-thirds and the rate spread explains none of the long-run change in the shortterm rate.

What happens when Equation 5 is estimated over periods when the yield curve is positively sloped and inverted is made clear by Figure 4, which presents the estimated regression lines corresponding to the regressions in the second and fourth columns of Table 3, and the estimated regression from Table 2. Including the observations when the yield curve was inverted biases the estimate of $\beta$ because the average level of the dependent variable, $(1 / 2)\left(r_{t \mid-1}^{3} t_{t}^{3}\right)$, and the independent variable, $\left(r_{t}^{6}-t_{t}^{3}\right)$, tend to be negative when the short-term rate spikes up one day and returns to its previous day's level the next. The reverse is also true. The left and right-hand-sides of Equation 5 tend to be positive when the short-term rate declines sharply and then rises to the previous day's level the next day. This is what accounts for the bias that Thornton (2000) identifies. When the observations are partitioned into the periods when the yield curve is either positively or negatively sloped, the effect of the bias is small, as long as observations where the variance of the short-term rate is extreme are omitted. When the equation is estimated over the entire sample (less the three extreme observations) it is the difference in the mean level of the dependent variable over these partitions that creates the impression that the slope of the yield curve accounts for 20 percent of the long-term change in the short-term rate.

The effect of shifts in the average level of the dependent variable is further illustrated in Table 4, which presents estimates of Equation 5 that includes a dummy variable, dum, which equals one when the yield curve is flat or inverted and zero otherwise. The estimate of $\beta$ drops to 0.34 , when dum is included. Moreover, the 
estimate of $\bar{R}^{2}$ drops only slightly when the rate spread is deleted. Comparing the estimates in the first column of Table 4 with those in the second column of Table 1, Panel A, shows that MM's conclusion that the expectations theory works better before the Fed's founding than after is almost entirely due to the bias of the conventional test of the expectations theory. The bias is extreme when the three controversial observations associated with the financial panic of 1907 are included. Even without these observations, the bias persists. Splitting the sample into positively and negatively sloped term structure, respectively, is a straightforward way to reduce the effect of the bias. When this is done there is no more evidence supporting the expectations theory before the Fed's founding than after.

\subsection{The Time-Varying Risk Premium Explanation}

It is interesting to note that the results presented in Table 4 appear to run counter to the time-varying risk premium explanation of why the conventional test rejects the expectations theory. According to this explanation, the estimate of $\beta$ is biased downward because the risk premium is time varying and is positively related to the rate spread. The estimates in Table 4, however, suggest that the reverse is true. Interpreting the constant term as an estimate of the risk premium, the estimated risk premium is large and statistically significant when the spread is zero or negative and zero when the spread is positive.

\section{Another Look at MM's Explanation}

MM argue that the Fed's founding also accounts for the well documented [Friedman and Schwartz (1963), Shiller (1980), MM, MMW, Barsky, Mankiw, Miron and Weil (1988), Barro (1989), Fishe (1991), and Fishe and Wohar (1990)] change in the 
time-series properties of interest rates after 1914. The question we now address is whether MM's explanation accounts for the change in the time-series properties of interest rates?

There were two significant changes in the stochastic properties of interest rates about the time of the Fed's founding. First, interest rates became much more persistent. For example, the estimated AR(1) coefficient for the 3-month New York bank loan rate increased from 0.75 for the period $1890.01-1910.12$ to 0.97 for the period $1920.01-$ 1933.12. In addition, there was a reduction in the seasonal in interest rates. MM conjecture that the marked change in the persistence of interest rates is due to the Fed's practice of smoothing short-term interest rates. Specifically, MM (pp. 225-26) argue that:

"During much of this period [after 1915] the Fed's announced policy was to stabilize (or even to peg) interest rates. One simple description of interest rate stabilization is...

$$
E_{t} \Delta r_{t+1}=0
$$

that is, the expected change in the short rate is zero...If equation (11) does describe the policy of stabilizing interest rates and if market participants knew it was the policy, then the short rate expected by the market would always equal the current short rate. The spread $\left(R_{t}-r_{t}\right)$ would always equal the term premium $\theta_{t}$. Fluctuations in the spread would have no predictive power for the path of the short rate." (italics added)

\subsection{Doubts about MM's Explanation}

This explanation has been questioned for several reasons. First, the exact timing of the change in the persistence of interest rates is controversial. While MMW date the shift in early 1915, Fishe (1991) and Kool (1995) present evidence that the change occurred somewhat later. ${ }^{12}$ Moreover, while MMW, Shiller (1980) and Canova (1991)

\footnotetext{
${ }^{12}$ For some additional reasons to doubt this explanation, see Stockman (1988).
} 
note a decline in the seasonal in interest rates after 1915, Canova (1991) suggests that the significance of the change in the seasonal pattern of nominal interest rates has been overemphasized. Moreover, Shiller (1980) finds no evidence of a change in the seasonal pattern of real interest rates after 1915. In addition, Clark (1986) finds an increase in persistence and a decline in the seasonal pattern of interest rates in the U.K., France, and Germany about this time. He suggests that the worldwide change in the behavior of interest rates is due to the demise of the gold standard and not to the founding of the Fed.

Miron (1986) suggests that the decline in the seasonal in interest rates was accompanied by an increase in the seasonal in bank credit. Toma and Holland (1991), however, argue that bank credit was not seasonal until the 1920s. They also show that there was a decline in the seasonal in bank credit (especially after 1993) that was not accompanied by an increase in the seasonal in interest rates.

Canova (1991) and Wheelock (1992) present evidence that suggests, if anything, it was the establishment of the Federal Reserve System, per se, and not the deliberate monetary policy actions of the Fed, that accounts for the reduction in the seasonal pattern of interest rates. Specifically, they argue that changes in the monetary base were due to banks' use of the Fed's discount window facility and to the elastic currency provision of the Federal Reserve Act, rather than from a desire of the Fed to smooth interest rates. They suggest that the change in the monetary base at the seasonal frequency was the result of an endogenous response of bank borrowing and currency and not the result of deliberate policy actions.

\subsection{Additional Reasons to Doubt MM's Explanation}


Our reading of Federal Reserve history also suggests that the Fed did not actively attempt to smooth interest rates for some time after its inception. Consistent with the analysis of Toma and Holland (1991), contemporary observers [e.g. Willis (1923), Riefler (1930), Whitney (1934a,b), and Harris (1933)] indicate that the Fed was relatively inactive during the early years of its existence. Indeed, the idea that the Fed could or should actively influence economic conditions did not gain favor until the 1920s. The coordination and centralization of discount rate policy and open market operations evolved gradually, and were not integrated until around 1923 [Whitney (1934b)].

Even if the Fed's objective was to smooth interest rates, we believe that such monetary policy could not account for the unpredictability of interest rates after the Fed's founding. The reason is that in order for this conclusion to hold, the market would have to have irrational expectations of Fed policy.

To smooth interest rates, the Fed establishes a target for the short-term interest rate and acts to offset changes in demand or supply to keep the rate close to a target level, $r_{t}^{m^{*}}$. Hence, if the Fed smoothes it, the short-term interest rate would be determined by

$$
r_{t}^{m} \nabla r_{t}^{m^{*}} \equiv \nabla_{t},
$$

where $v_{t} \sim \operatorname{iid}\left(0, \sigma_{v}^{2}\right)$ represents the Fed's control error. According to Equation 11, MM's condition that the expected change in the short-term rate equals zero implies,

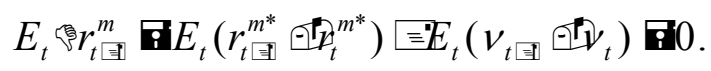

Given MM's maintained assumption (p. 213, Equation 1) that the $t^{\text {th }}$-period short-term rate is known when the $t^{\text {th }}$-period long-term rate is determined, Equation 12 can be written as,

$$
E_{t} \Delta r_{t+1}^{m}=E_{t}\left(r_{t+1}^{m^{*}}-r_{t}^{m^{*}}\right)-v_{t} .
$$


It is clear from Equation 13 that $E_{t} r_{t \mid \mathbb{1}}^{m} 0$ can occur only if the market does not anticipate that the Fed will change its target and there is no control error or if the Fed continuously adjusts the target to the prevailing short rate. The latter possibility can be dismissed.

It is also unlikely that the Fed could control interest rates without error. ${ }^{13}$ But even if it could, rational expectations suggests that it is unlikely that the first term on the right-hand-side of Equation 13 would be zero. The first term on the right-hand-side of Equation 13 can be zero only if 1) the market formed rational expectations of Fed policy but the Fed never changes the target or 2) the target is changed but the market never anticipates policy. Figure 2 suggests that the first possibility is unlikely. The 3 -month time loan rate was constant only from the late 1930 s to the late 1940 s. At other times, there was considerable month-to-month variation in interest rates. Hence, if the Fed is responsible for the observed behavior in the 3-month rate, it appears that the target was changed frequently. ${ }^{14}$

Consequently, the first term on the rhs of Equation 13 could be zero only if the market formed irrational expectations of Fed policy. Specifically, the market would have to expect the Fed to maintain its target at the current level, despite the fact that the Fed repeatedly changes it. When the Fed is targeting it, the rate should change with changes in policy. If the market is forming rational expectations of policy, the market should be

\footnotetext{
${ }^{13}$ Indeed, recent evidence shows that the funds rate differs from the funds rate target at virtually any frequency.

${ }^{14}$ This is consistent with recent evidence. For example, Rudebusch (1995) reports that the Fed adjusted its target for the federal funds rate 98 times during the period September 23, 1947 to October 5, 1979. This is an average of one change about every two and a half weeks. Changes in the funds rate target have been less frequently in recent years, however, for the period 1983-97; the funds rate target was changed about once every two months.
} 
able to predict policy changes and, hence, changes in the rate. Hence, it is hard to see why the interest rate should be less predictable when the Fed is targeting it.

Indeed, Goodfriend (1991) argues that central banks smooth short-term rates in order to make them more predictable. By increasing the predictability of the short-term rate, the central bank can better influence long-term rates. ${ }^{15}$ Hence, if Goodfriend is correct, the Fed smoothes short-term rates to make them more predictable.

It could be, however, that the Fed's objective was more limited in 1915.

Specifically, the objective may have been simply to reduce the seasonal behavior of rates. In this case, the market surely would have come to expect a smaller seasonal spike, just as it came to expect a larger one before the Fed's founding. Moreover, MMW show that the persistence of the 3-month time loan rate changed, even after the change in the seasonal had been accounted for. Hence, it was not only the seasonal pattern of interest rates that changed.

\subsection{A Conjecture of Our Own}

Our reading of the literature suggests that the establishment of the Fed's discount window and provision for an elastic currency may have played a role in reducing the seasonal in interest rates. It seems unlikely to us, however, that these facilities had a significant effect on the persistence of interest rates. Among the alternative candidates that have been suggested in the literature are the demise of the gold standard and the consequences of war financing. To this list, we would like to speculate a third possibility. Specifically, we conjecture that the marked change in interest rates from a

\footnotetext{
${ }^{15}$ Poole (1991), Rudebusch (1995) and Woodford (1999) have endorse this argument. Indeed, Woodford (1999, p. 9) argues that Goodfriend (1991) has provided "the essential insight into why a commitment to inertial behavior may be optimal for a central bank."
} 
stationary AR process to a near random walk process might be due to an increase in the efficiency of financial markets about this time.

According to the efficient market hypothesis, the current rate reflects all of the information that the market has about the future behavior of the rate, including, but not limited to, expectations of future Fed policy actions. As markets become more efficient, period-to-period changes in rates should become less predictable. Hence, the marked change in the time-series behavior of interest rates is consistent with an increase in market efficiency.

There is some other evidence that is consistent with the increased-marketefficiency hypothesis. Specifically, the spread between rates on similar maturity assets declined as well. This is evident in Figure 2. Burgess (1927, pp. 281-95) attributes the marked decline in interest rate differentials across maturities and across the U.S. after 1914 to changes in financial markets. Moreover, Eckhart (1932) and Burgess (1927) suggest that the Fed may have played a role in enhancing the efficiency of financial markets. Burgess (1927) suggests that the operations of the Federal Reserve System played a significant role in this process by improving the transfer of funds across the U.S. ${ }^{16}$

Noting that nominal interest rates appear to be mean reverting before the founding of the Fed but not after, Clark (1986) has suggested that the change in the time-series properties of interest rates is due to the demise of the gold standard in 1914, rather than to

\footnotetext{
${ }^{16}$ MM's data reflect the narrowing of interest rate differentials noted by Burgess and others about this time. The average spread between the 3- and 6-month rate was 12.1 basis points for the period 1915-33, with a standard deviation of 21.6 basis points. Prior to 1915 the average spread was 34.9 basis points with a standard deviation of 77 basis points. After 1934, the variation in the rate spread was further reduced, as was the month-to-month variation in both rates. Indeed, there were just 13 unique values of the spread during the 1915-33 period and seven during the 1934-58 period. Moreover, the spread was either zero or 25 basis points for nearly 75 percent of the months [393 out of 528] during the post- 1914 period.
} 
the Fed's founding. ${ }^{17}$ We see no reason why it must be either or. ${ }^{18}$ It could be that the confluence of these two events accounts for the marked change in the behavior of interest rates, as shown in Figure 2. On the one hand, the demise of the gold standard removed the mean-reversion tendency, and hence the low-frequency predictability, from interest rates. On the other, increased market efficiency—perhaps enhanced by the creation of the Federal Reserve System — caused the spreads between similar term assets to shrink, while simultaneously removing the high-frequency predictability from interest rates. Whatever the explanation, it seems unlikely that the practice of smoothing interest rates- to whatever degree that such a policy was pursued by the Fed at this time- - had much to do with the marked change in the behavior of interest rates after 1914.

\section{Conclusions}

The expectations theory of the term structure is frequently rejected regardless of the test used. One test, however, tends to produce results that have been interpreted as supportive of the expectations theory. A particularly important application of this is Mankiw and Miron (1986), who find that the expectations theory is less soundly rejected before the founding of the Fed than after. They argue that their finding is due to the marked change in interest rates from a stationary process to a near random walk about this time. They attribute the change in the stochastic process of interest rates and the failure of the expectations theory to the Fed's policy of smoothing interest rates.

We show that Mankiw and Miron's finding that the expectations theory works well prior to the Fed's founding is due the bias in the test that they employ. Specifically, the

\footnotetext{
${ }^{17}$ Clark (1986) and Morgenstern (1959) show a similar change in the behavior of interest rates worldwide after 1914.

${ }^{18}$ Considerable effort has been devoted to distinguishing between these competing hypotheses [Barsky, Mankiw, Miron and Weil (1988), Mankiw and Miron (1991), Miron (1986), Toma and Holland (1991), and Stockman (1988)].
} 
test is biased in favor of the expectations theory the more variable the short-term rate is relative to the long-term rate. Much of the bias is shown to be associated with three extreme observations associated with the financial panic of 1907, when the 3-month time loan rate that Mankiw and Miron use rose significantly and temporarily relative to the 6month time loan rate. When these observations and the remaining bias is accounted for, the evidence is that the expectations theory works no better before the Fed's founding than after. While it is sometimes the case that extreme observations provide the most useful information, this is not the case here. The most extreme of these observations are associated with financial market uncertainty and are subject to measurement problems. In addition, we argue that it is unlikely that a Fed policy of interest rate smoothing accounts for the change in the behavior of interest rates about this time. We note that many contemporary commentators noted that activist monetary policy did not commence until the early 1920s. This view is supported by evidence suggesting that the behavior of bank credit was determined endogenously by bank borrowing and currency demand. We then argue that, even if monetary policy had been focused on controlling short-term interest rates, it is unlikely that such a policy could account for the unpredictability of changes in short-term rates. For this explanation to account for the change in the behavior of interest rates, the Fed would have to have held its target constant, which is inconsistent with the observed behavior of the short-term rate, or the market would have had to have formed irrational expectations of policy. 


\section{REFERENCES:}

Andrew, A. Piatt. Statistics for the United States 1867-1909. (1910), Government Printing Office, Washington D.C.

Barksy, Robert B, Gregory N. Mankiw, Jeffrey A. Miron and David N. Weil. "The Worldwide Change in the Behavior of Interest Rates and Prices in 1914," European Economic Review (June 1988), pages 1123-47.

Barro, Robert J. “Interest Rate Targeting," Journal of Monetary Economics (January 1989), 3-30.

Bekaert, Geert, Robert J. Hodrick and David A. Marshall. "On Biases in Tests of the Expectations Hypothesis of the Term Structure of Interest Rates," Journal of Financial Economics (June 1997), 309-48.

Bekaert, Geert and Robert J. Hodrick. "Expectations Hypotheses Tests," NBER Working Paper 7609, March 2000.

Burgess, W. Randolph. The Reserve Banks and the Money Market, (1927), Harper \& Brothers Publishers: New York.

Campbell, John Y. and Robert J. Shiller. "Yield Spreads and Interest Rate Movements: A Bird's Eye View," Review of Economic Studies (May 1991), 495-514.

Canova, Fabio. "The Sources of Financial Crises: Pre- and Post-Fed Evidence," International Economic Review (August 1991), 689-713.

Clarida, Richard, Jordi Gali and Mark Gertler. "The Science of Monetary Policy: A New Keynesian Perspective,” Journal of Economic Literature (December 1999), 16611707.

Clark, Truman. "Interest Rate Seasonals and the Federal Reserve," Journal of Political Economy (February 1986), 76-125.

Eckhart, Benjamin H. The New York Money Market vol. III, (1932), Columbia University Press: New York.

Fishe, Raymond P.H. "The Federal Reserve Amendments of 1917: The Beginning of a Seasonal Note Issue Policy," Journal of Money, Credit and Banking (August 1991, part 1), 308-326.

Fishe, Raymond P.H. and Mark Wohar, "The Adjustment of Expectations to a Change in Regime: Comment," The American Economic Review (September 1990), 968976. 
Friedman, Milton and Anna J. Schwartz. A Monetary History of the United States, 18671960, Princeton: Princeton University Press, 1963).

Froot, Kenneth A. "New Hope for the Expectations Hypothesis of the Term Structure of Interest Rates," Journal of Finance (June 1989), 283-305.

Goodfriend, Marvin. "Interest Rates and the Conduct of Monetary Policy," CarnegieRochester Conference Series on Public Policy (Spring 1991), 7-30.

Hardouvelis, Gikas A. "The Predictive Power of the Term Structure during Recent Monetary Regimes," Journal of Finance (June 1988), 339-56.

"The Term Structure Spread and Future Changes in Long and Short Rates in the G7 Countries: Is There a Puzzle?” Journal of Monetary Economics (April 1994), 255-83.

Harris, Seymour E. Twenty Years of Federal Reserve Policy, vol 1+2 (1933), Harvard University Press; Cambridge, Massachusetts.

James, John A. Money and Capital Markets in Postbellum America (1978), Princeton University Press; Princeton.

Kool, Clemens J.M. "War Finance and Interest Rate Targeting: Regime Changes in 19141918," Explorations in Economic History (July 1995), 365-382.

Mankiw, N. Gregory "The Term Structure of Interest Rates Revisited (with comments and discussion)," Brookings Papers on Economic Activity (1986,1), 61-110.

Mankiw, N. Gregory, and Jeffery A. Miron. "The Changing Behavior of the Term Structure of Interest Rates," Quarterly Journal of Economics (May 1986), 211-28.

Mankiw, N. Gregory, and Jeffery A. Miron. "Should the Fed Smooth Interest Rates? The Case of Seasonal Monetary Policy, " Carnegie Rochester Conference Series on Public Policy (Spring 1991), 41-69.

Mankiw, N. Gregory, Jeffery A. Miron and David N. Weil. "The Adjustment of Expectations to a Change in Regime: A Study of the Founding of the Federal Reserve," The American Economic Review (June 1987), 358-374.

Mankiw, N. Gregory, Jeffery A. Miron and David N. Weil. "The Adjustment of Expectations to a Change in Regime: Reply," The American Economic Review (September 1990), 977-979.

Miron, Jeffrey A. "Financial Panics, the Seasonality of the Nominal Interest Rate, and the Founding of the Fed," The American Economic Review (March 1986), 125-140. 
Morgenstern, Oskar. International Financial Transactions and Business Cycles (1959), Princeton University Press; Princeton.

Poole, William. "Interest Rates and the Conduct of Monetary Policy: A Comment," Carnegie Rochester Conference Series on Public Policy (Spring 1991), 31-39.

Riefler, Winfield W. Money Rates and Money Markets in the United States (1930), Harper \& Brothers Publishers: New York.

Rudebusch, Glenn D. "Federal Reserve Interest Rate Targeting, Rational Expectations, and the Term Structure," Journal of Monetary Economics (April 1995), 245-74.

Schotman, Peter C. "Small Sample Properties of the Regression Test of the Expectations Model of the Term Structure," Economics Letters (December 1997), 129-34.

Shiller, Robert J. "Can the Fed Control Real Interest Rates?" in S. Fisher, ed. Rational Expectations and Economic Policy. Chicago: University of Chicago Press, 1980, 117-67.

, John Y. Campbell and Kermit L. Schoenholtz. "Forward Rates and Future Policy: Interpreting the Term Structure of Interest Rates," Brookings Papers on Economic Activity (1983), 173-217.

Stockman, Alan C. "The Worldwide Change in the Behavior of Interest Rates and Prices in 1914: Comments," European Economic Review (June 1988), 1150-54.

Thornton, Daniel L. "The Bias in the Conventional Test of the Expectations Theory: Resolving the Anomalies at the Very Short End of the Term Structure," Federal Reserve Bank of St. Louis Working Paper 2000-003A, 2000.

Toma, Mark, and Steven A. Holland. "The Role of the Federal Reserve as "Lender of Last Resort" and the Seasonal Fluctuation of Interest Rates," Journal of Money, Credit, and Banking (November 1991), 659-76.

Tzavalis, Elias, and Michael R. Wickens. "Explaining the Failures of the Term Spread Models of the Rational Expectations Hypothesis of the Term Structure," Journal of Money, Credit and Banking (August 1997), 364-80.

Wheelock, David C. "Seasonal Accommodation and the Financial Crises of the Great Depression: Did the Fed 'Furnish an Elastic Currency?'" Federal Reserve Bank of St. Louis Review (November/December 1992), 3-18.

Whitney, Caroline "Discount Policy" in H.P. Willis and J.M. Chapman (eds). The Banking Situation: American Post-War Problems and Developments (1934a), Columbia University Press; New York, 690-724. 
Whitney, Caroline. Experiments in Credit Control The Federal Reserve System (1934b), Columbia University Press; New York.

Willis, Henry P. The Federal Reserve System: Legislation, Organization and Operation (1923), The Ronald Press Company: New York.

Woodford, Michael. “Optimal Monetary Policy Inertia," unpublished manuscript, Princeton University, 1999. 
TABLE 1 The Predictive Power of the Spread

\begin{tabular}{|c|c|c|c|c|}
\hline & \multicolumn{4}{|c|}{ Panel A: Monthly data } \\
\hline Period & 1890-1914 & 1915-1933 & $1934-1951$ & $1951-1958$ \\
\hline \multirow[t]{2}{*}{ Constant } & -0.24 & -0.07 & 0.06 & 0.04 \\
\hline & $(0.06)$ & $(0.05)$ & $(0.03)$ & $(0.02)$ \\
\hline \multirow[t]{2}{*}{$r_{t}^{n} \Theta_{t}^{m}$} & 0.67 & 0.42 & -0.23 & -0.34 \\
\hline & $(0.04)$ & $(0.16)$ & $(0.13)$ & $(0.24)$ \\
\hline $\bar{R}^{2}$ & 0.38 & 0.04 & 0.06 & 0.02 \\
\hline D.W. & 0.81 & 0.70 & 0.77 & 0.49 \\
\hline s.e. & 0.66 & 0.41 & 0.07 & 0.12 \\
\hline \multirow[t]{2}{*}{ Number of Obs } & 300 & 228 & 207 & 93 \\
\hline & \multicolumn{4}{|c|}{ Panel B: Quarterly data } \\
\hline Period & $1890-1914$ & $1915-1933$ & $1934-1951$ & $1951-1958$ \\
\hline \multirow[t]{2}{*}{ Constant } & -0.29 & -0.06 & 0.06 & 0.04 \\
\hline & $(0.06)$ & $(0.07)$ & $(0.04)$ & $(0.03)$ \\
\hline \multirow[t]{2}{*}{$r_{t}^{n} \sim_{t}^{m}$} & 0.76 & 0.42 & -0.25 & -0.33 \\
\hline & $(0.06)$ & $(0.20)$ & $(0.16)$ & $(0.26)$ \\
\hline $\bar{R}^{2}$ & 0.40 & 0.03 & 0.06 & -0.01 \\
\hline D.W. & 2.06 & 1.88 & 1.77 & 1.73 \\
\hline s.e. & 0.59 & 0.42 & 0.07 & 0.13 \\
\hline Number of Obs & 100 & 76 & 69 & 31 \\
\hline
\end{tabular}


TABLE 2 The Effect of the Financial Panic of 1907

\begin{tabular}{l|c}
\hline Sample & Financial Panic deleted \\
\hline Constant & -0.23 \\
\hline & $(0.07)$ \\
\hline$r_{t}^{n}-\sigma_{t}^{m}$ & 0.64 \\
\hline & $(0.09)$ \\
\hline $\bar{R}^{2}$ & 0.20 \\
\hline D.W. & 0.78 \\
\hline s.e. & 0.66 \\
\hline $\mathrm{N}$ & 297 \\
\hline Newey-West HAC standard errors are reported in parentheses
\end{tabular}

Newey-West HAC standard errors are reported in parentheses 
TABLE 3 The Slope of the Yield Curve: 1890.01-1914.12

\begin{tabular}{l|c|c|c|c}
\hline Sample & $r_{t}^{n} \oplus r_{t}^{m}$ & $r_{t}^{n} \odot r_{t}^{m}$ & $r_{t}^{n} \square r_{t}^{m}$ & $r_{t}^{n} \square r_{t}^{m}$ \\
\hline Constant & -0.17 & -0.01 & -0.23 & -0.41 \\
\hline & $0.04)$ & $(0.10)$ & $(0.12)$ & $(0.13)$ \\
\hline$r_{t}^{n} \sigma_{t}^{m}$ & 0.64 & 0.42 & 0.66 & 0.21 \\
\hline & $(0.06)$ & $(0.13)$ & $(0.05)$ & $(0.16)$ \\
\hline $\bar{R}^{2}$ & 0.42 & 0.04 & 0.78 & 0.01 \\
\hline D.W. & 0.82 & 0.78 & 0.89 & 0.64 \\
\hline s.e. & 0.63 & 0.64 & 0.55 & 0.47 \\
\hline N & 234 & 202 & 32 & 29 \\
\hline
\end{tabular}

Newey-West HAC standard errors are reported in parentheses 
TABLE 4 Another Look at the Effect of the Financial Panic of 1907

\begin{tabular}{l|c|c}
\hline & $1890.01-1914.12$ & $1890.01-1914.12$ \\
\hline Constant & 0.01 & 0.26 \\
\hline$d u m$ & $(0.08)$ & $(0.05)$ \\
\hline & -0.44 & -0.72 \\
\hline$r_{t}^{n}-r_{t}^{m}$ & $(0.12)$ & $(0.08)$ \\
\hline $\bar{R}^{2}$ & 0.34 & -- \\
\hline D.W. & $(0.09)$ & -- \\
\hline s.e. & 0.23 & 0.21 \\
\hline $\mathrm{N}$ & 0.83 & 0.91 \\
\hline $\mathrm{N}$ & 0.65 & 0.65 \\
\hline
\end{tabular}

Newey-West HAC standard errors are reported in parentheses 


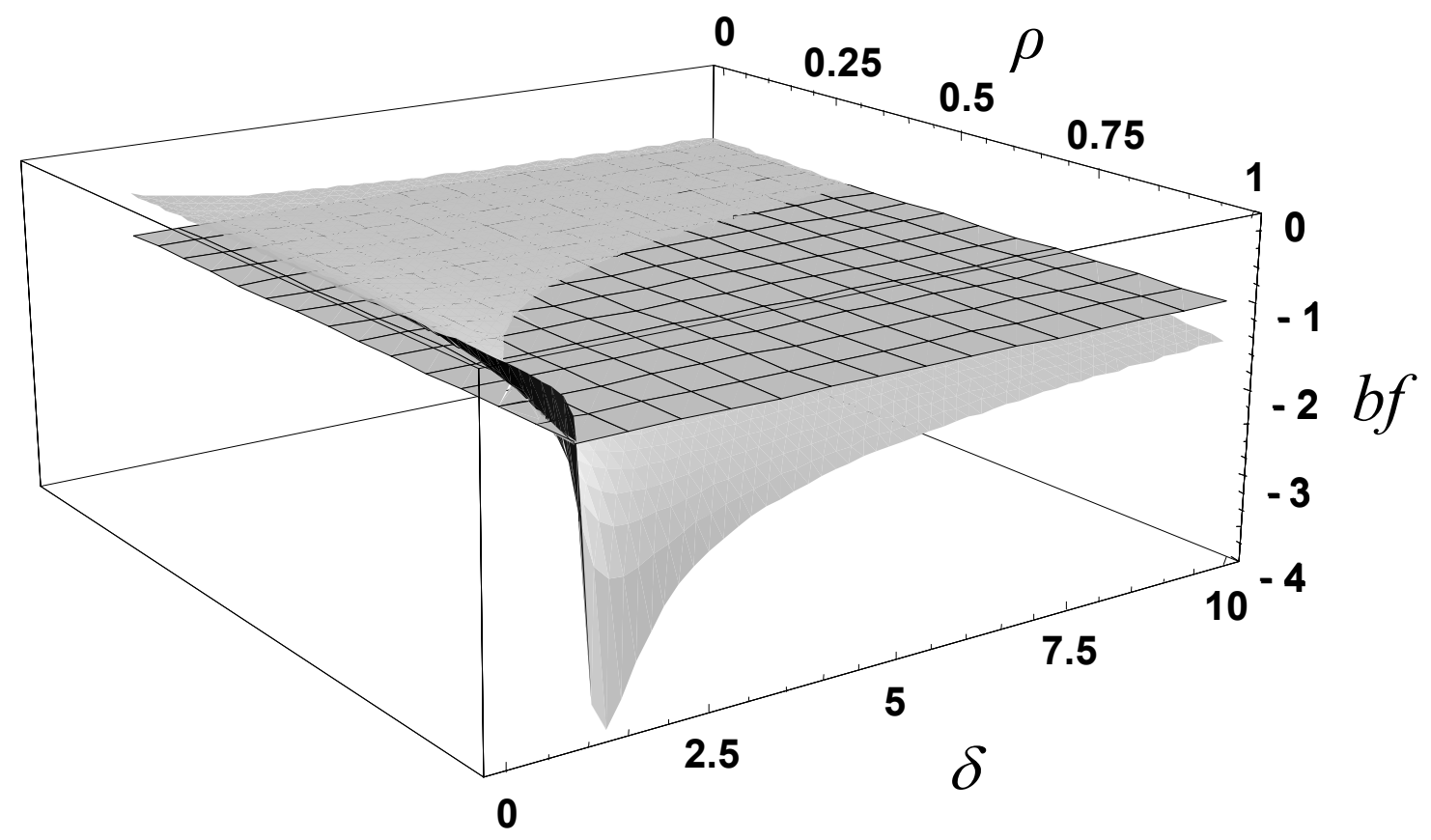

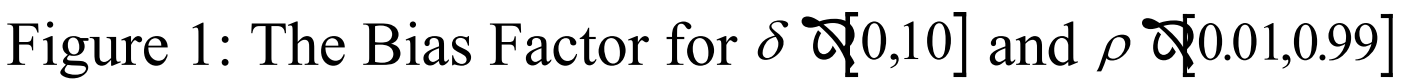


Figure 2: Nominal Interest Rate on Time Loans (1890 - 1958)

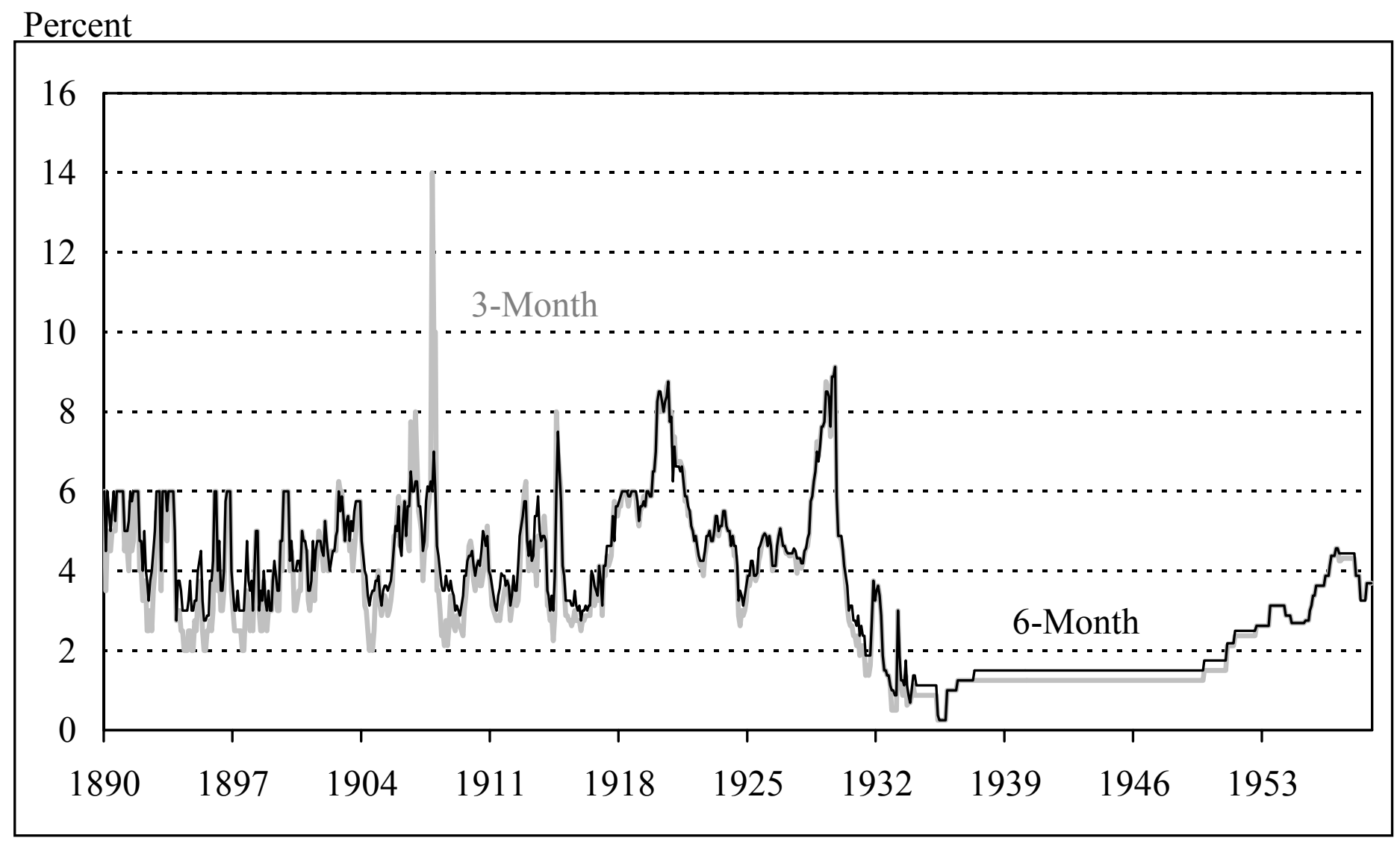


Figure 3

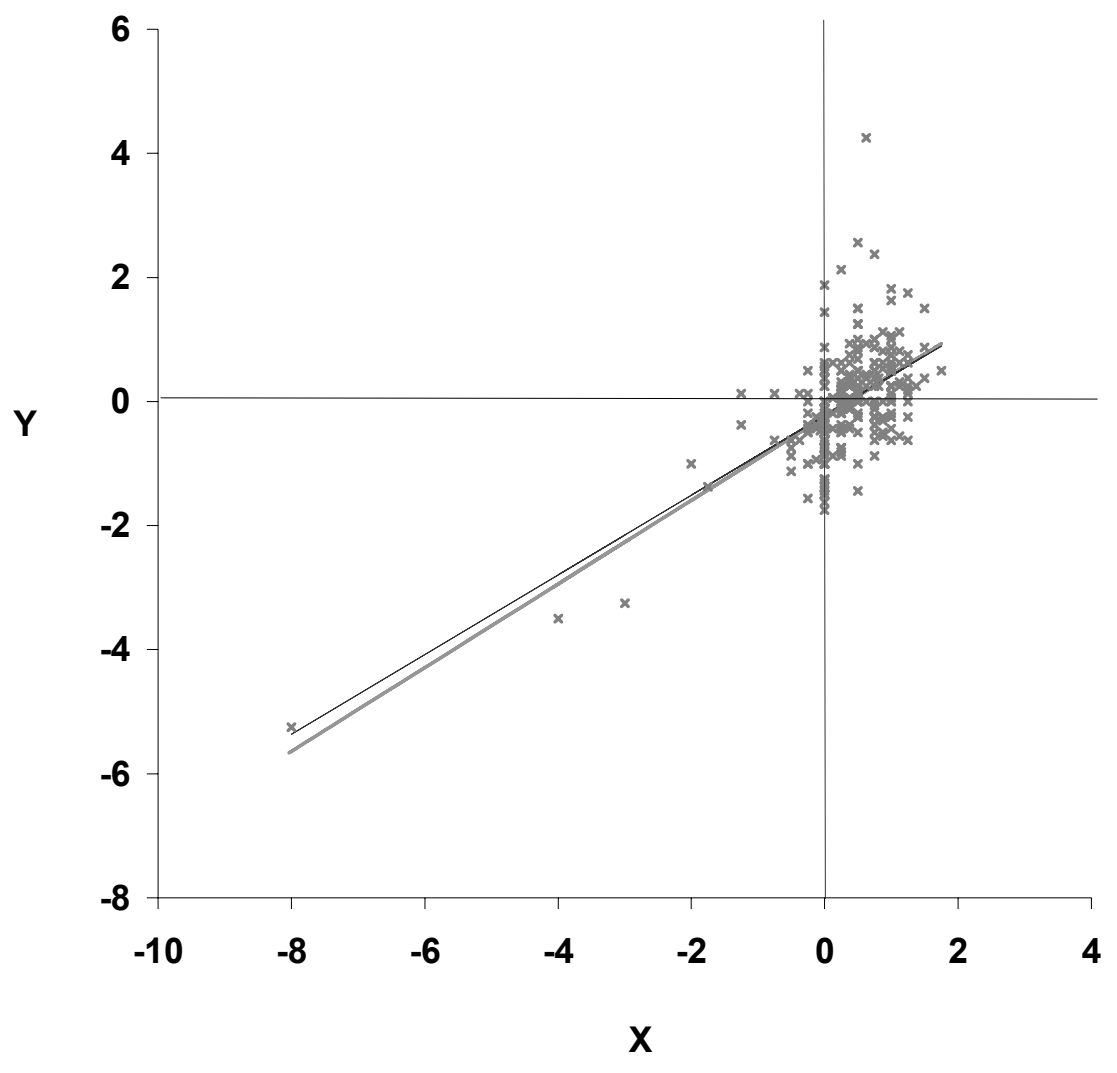

All Observations__ Panic 1907 Deleted

$$
X \boldsymbol{\nabla} r_{t}^{6}-r_{t}^{3} \quad Y \text { 穴 } \frac{1}{2} \boldsymbol{\varphi}_{\text {: }}^{3} r_{t}^{3} \boldsymbol{h}
$$


Figure 4

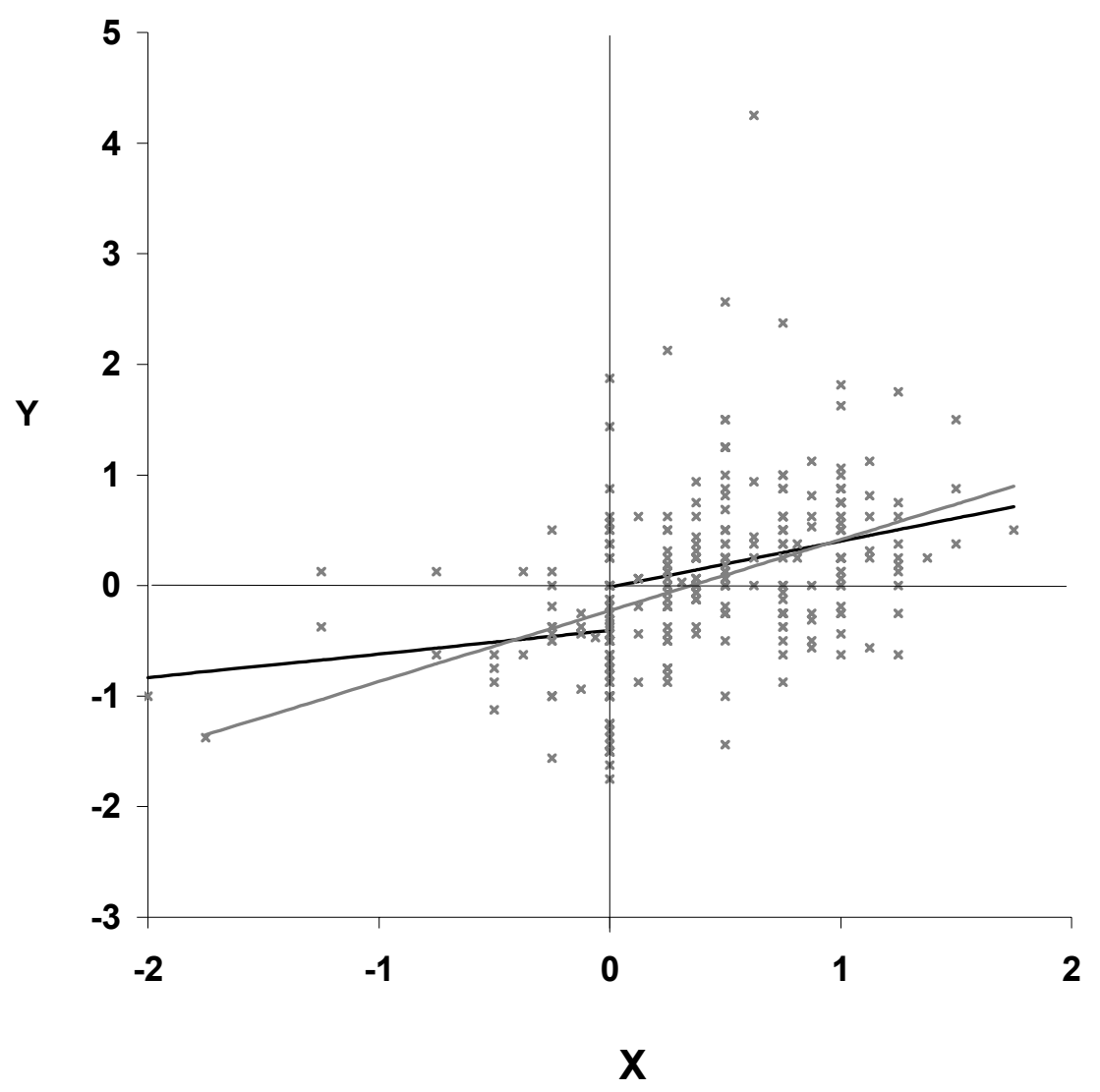

— Positive/Negative Observations

_-All Observations (with panic 1907 deleted)

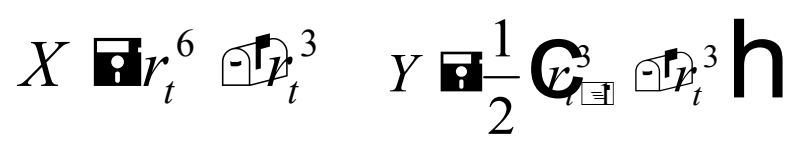

